\title{
Intensive care unit discharge: mind the gap!
}

\author{
Cristian Deana ${ }^{*}$ D, Giovanni Sermann and Amato De Monte
}

\begin{abstract}
Mortality after intensive care discharge is a hot topic in critical care medicine. Many factors probably play a role: patient's comorbidities and severity of the disease may have great impact on mortality. However it should be taken into account also the level of care that characterizes the ward in which the patient is discharged to. A soft transition from intensive care units to the other hospital wards is desirable to avoid the traumatic step that the fragile post-ICU patient has to face with.
\end{abstract}

Keywords: Critically ill patients, Mortality, Intermediate level of care, ICU discharge

Letter to the Editor.

We read the work by Hamsen and Colleagues about mortality in severely injured patients with great interest [1].

From their analysis of a large dataset, they concluded that $17.7 \%$ of all injured patients admitted to ICU and discharged from the unit alive, nevertheless died during their hospital stay.

The authors proposed several possible explanations to interpret their findings: patient characteristics (older and sicker ones were more likely to die), the type of trauma, the level of intensive treatments received during ICU stay, and the level of patient "determination" (or "will") to live are proposed to be associated with the probability of in-hospital death.

In our opinion, the level of the intensity of care characterising the ward onto which the patients were discharged was not sufficiently considered in their analysis of the factors associated with mortality probability.

ICUs provide the highest level of care intensity in terms of technology, level of organization, monitoring, organ support and human resources. Around the world,

This comment refers to the article available at https://doi.org/10.1186/ s12871-020-01159-8.

* Correspondence: deana.cristian@gmail.com

Anesthesia and Intensive Care 1, Department of Anesthesia and Intensive Care Medicine, Academic Hospital "S. Maria della Misericordia", Piazzale S. M. della Misericordia, 15, 33100 Udine, Italy the average nurse to patient ratio in the ICU tends towards $1: 1$, and is rarely lower than 1:2. This permits the continuous monitoring of a patient so that any changes are detected in almost real time, enabling physicians and nurses to do their utmost in their care and rehabilitation of critically ill patients.

General wards are very different and adhere to care models that differ to those of the ICU: continuous monitoring and the provision of personnel could be inadequate to permit the soft transition of patients from the ICU onto the general ward.

In fact, patients who experience ICU care for a long time require intensive rehabilitation in dedicated units to reduce and treat post-intensive care syndrome (PICS) [2].

This is important for returning autonomous and nondisabled people to society.

Capuzzo et al., in a large European study, demonstrated that the sickest patients admitted to the ICU benefit - in terms of reduced mortality - from the intermediate-level care units (IMCU): patients discharged to the IMCU had a $5 \%$ lower probability of mortality [3].

Many possible reasons were proposed to account for this result; however, the primary one seems to be that the IMCU is able to guarantee a smooth treatment path

(c) The Author(s). 2021 Open Access This article is licensed under a Creative Commons Attribution 4.0 International License, which permits use, sharing, adaptation, distribution and reproduction in any medium or format, as long as you give appropriate credit to the original author(s) and the source, provide a link to the Creative Commons licence, and indicate if changes were made. The images or other third party material in this article are included in the article's Creative Commons licence, unless indicated otherwise in a credit line to the material. If material is not included in the article's Creative Commons licence and your intended use is not permitted by statutory regulation or exceeds the permitted use, you will need to obtain permission directly from the copyright holder. To view a copy of this licence, visit http://creativecommons.org/licenses/by/4.0/. The Creative Commons Public Domain Dedication waiver (http://creativecommons.org/publicdomain/zero/1.0/) applies to the data made available in this article, unless otherwise stated in a credit line to the data. 
without patients being subjected to any sudden changes in the intensity of their care.

Another interesting finding of the study by Hamsen and Colleagues is that, following ICU discharge, nearly $70 \%$ of non-survivor patients died within 8 days.

Similar results were found by Valent and Colleagues, who showed that in a large mixed cohort of ICU patients up to $50 \%$ of people aged 80 years or older died after being discharged from the ICU [4].

These results certainly implicate the necessity for further investigations into possible predictive factors linked to failed recovery after ICU discharge.

Today's reality entails scarcity of resources, meaning that energies are sometimes prioritised towards those with higher chances of overcoming their critical illness.

The COVID-19 pandemic has taught us that during times distinguished by resource constraints and a simultaneous high demand for intensive medical care, doctors are called upon to make choices regarding who to invest in and who to allocate more basic treatments.

Critical care research must try to identify predictive criteria relating to the success or failure of the resuscitation treatment being provided to the patient. Big data sets will hopefully help us identify such criteria in this times when evidence based medicine is highly needed [5].

What we must strive for is the possibility to guarantee maximal levels of care to all critically ill patients in ICU, and to avoid transferring them to a lower level of care too early. So, please, mind the gap!

\section{Abbreviations}

ICU: Intensive care unit; PICS: Post intensive care syndrome;

IMCU: Intermediate care unit; COVID-19: Coronavirus

\section{Authors' contributions}

$C D, G S$ and ADM contributed to drafting the manuscript. All authors revised and have approved the final version of the manuscript.

\section{Funding}

No funding was received.

Availability of data and materials

Not applicable.

Ethics approval and consent to participate

Not applicable.

\section{Consent for publication}

Not applicable.

\section{Competing interests}

Cristian Deana declares to be Associate Editor of BMC Anesthesiology. The other Authors have nothing to declare.

Received: 30 October 2020 Accepted: 20 January 2021

Published online: 08 February 2021

\section{References}

1. Hamsen U, Drotleff N, Lefering R, et al. Mortality in severely injured patients: nearly one of five non-survivors have been already discharged alive from ICU. BMC Anesthesiol. 2020;20:243. https://doi.org/10.1186/s12871-020-01159-8.
2. Kamdar BB, Suri R, Suchyta MR, et al. Return to work after critical illness: a systematic review and meta-analysis. Thorax. 2020;75:17e27. https://doi.org/10.1136/thoraxjnl-2019-213803.

3. Capuzzo M, Volta C, Tassinati T, Working Group on Health Economics of the European Society of Intensive Care Medicine, et al. Hospital mortality of adults admitted to Intensive Care Units in hospitals with and without Intermediate Care Units: a multicentre European cohort study. Crit Care. 2014;18(5):551. https://doi.org/10.1186/s13054-014-0551-8.

4. Valent F, Sermanne G, De Monte A. One-year post-ICU discharge survival among patients receiving long-term intensive care in the University Hospital of Udine, Italy. Trends Anaesthesia Crit Care. 2018. https://doi.org/10.1016/j.tacc.2018.07.011.

5. Deana C. The COVID-19 pandemic: is our medicine still evidence-based? Ir J Med Sci. 2020. https://doi.org/10.1007/s11845-020-02258-8.

\section{Publisher's Note}

Springer Nature remains neutral with regard to jurisdictional claims in published maps and institutional affiliations.
Ready to submit your research? Choose BMC and benefit from:

- fast, convenient online submission

- thorough peer review by experienced researchers in your field

- rapid publication on acceptance

- support for research data, including large and complex data types

- gold Open Access which fosters wider collaboration and increased citations

- maximum visibility for your research: over $100 \mathrm{M}$ website views per year

At BMC, research is always in progress.

Learn more biomedcentral.com/submissions 